\title{
PROSPECTS FOR THE DEVELOPMENT OF HEALTH TOURISM ON LAKE RAY IN THE ALMATY REGION OF THE REPUBLIC OF KAZAKHSTAN
}

\author{
Yerkin TOKPANOV \\ Zhetysu University named after I. Zhansugurov, Faculty of Natural Sciences, \\ Zhansugurov, Tadlykorgan, Kazakhstan, e-mail: tokpanov60@mail.ru \\ Emin ATASOY* \\ Bursa Uludag University, Faculty of Education, Gorukle, Bursa, Turkey, e-mail: eatasoy@uludag.edu.tr
}

Erbolat MENDYBAYEV

K. Zhubanova Aktobe Regional State University, Department of Ecology, Alia Moldagulova, Aktobe, Kazakhstan, e-mail: beskurek@mail.ru

\section{Bakhadurkhan ABDIMANAPOV}

Kazakh National Pedagogical University named after Abay, Department of Geography, Ecology and Tourism, Dostyk Almaty, Kazakhstan, e-mail: bahadur_66@mail.ru

\section{Yerlan ANDASBAYEV}

Zhetysu University named after I. Zhansugurov, Faculty of Natural Sciences, Zhansugurov, Tadlykorgan, Kazakhstan, e-mail: erl872@mail.ru

\section{Roza MUKHITDINOVA}

Zhetysu University named after I. Zhansugurov, Faculty of Natural Sciences, Zhansugurov, Tadlykorgan, Kazakhstan, e-mail: mukhitdinova.ra@gmail.com

\section{Zhansulu INKAROVA}

L.N. Gumilyov Eurasian National University, Faculty of Natural Sciences, Nur-Sultan, Republic of Kazakhstan, e-mail: inkarzh@mail.ru

\author{
Citation: Tokpanov, Y., Atasoy, E., Mendybayev, E., Abdimanapov, B., Andasbayev, Y., Mukhitdinova, R., \& Inkarova, Zh. (2021). \\ PROSPECTS FOR THE DEVELOPMENT OF HEALTH TOURISM ON LAKE RAY IN THE ALMATY REGION OF THE \\ REPUBLIC OF KAZAKHSTAN. GeoJournal of Tourism and Geosites, 37(3), 888-893. https://doi.org/10.30892/gtg.37320-722
}

\begin{abstract}
Lake Ray is a unique natural object of the Republic of Kazakhstan. It is located in the Balkhash depression of the Almaty region. The waters of the lake are characterized by a peculiar hydrochemical and mineral composition, which can be used for various types of health tourism and recreation. The study aimed to show scientifically substantiated therapeutic and healthimproving attractiveness of the territory of lake basins, to attract investment in the development of tourism. This study presents the physicochemical and spectral analysis of water and therapeutic mud. Organoleptic characteristics (color, odor, consistency, structure) and sanitary and microbiological indicators of the declared sample of mud, physical and chemical indicators of the declared sample of water have been determined. The results indicated that the physicochemical composition of water and brine met the regulatory sanitary and epidemiological requirements and could be used in stationary medical institutions and physiotherapy. Lake Ray in the Republic of Kazakhstan has a unique variety of hydromineral recreational resources.
\end{abstract}

Key words: Lake Ray, physical and chemical analysis, trace elements, recreation, health tourism

\section{INTRODUCTION}

Health tourism, as a type of ecological tourism, is a kind of spa treatment and considers the organization of health improvement of the population from the point of view of travel technology (Akhmedenov, 2020; Constable, 2014; Dunets et al., 2019) and is achieved through the formation of a tourist product, which is based on a medical or health-improving technology that improves the quality of life by fully satisfying the need for rest, health improvement and treatment using various components of the natural complex (landscape, comfortable climate, healthy regime, change of environment, etc.) and - such methods of influence on the human body as balneo-, peloid-, landscape-, thalasso- and climatotherapy (Akhmedenov et al., 2017; Egorina et al., 2016; Erdavletov, 2010). Medical travel has a long history. Even the ancient Greeks and Romans used healing springs and places with a favorable climate in order to improve their health. Not only sick people arrived at the resorts, but also healthy people who wanted to relax and had sufficient funds for this (Carretero et al., 2014; Beketova et al., 2019; Khomitch et al., 2019; Dracheva, 2010). Recently, the health tourism market has been undergoing changes. Traditional resorts are becoming more and more multifunctional wellness centers designed for a wide range of consumers. There are a growing number of people around the world who want to keep fit and need restorative anti-stress programs (Suleimenov et al., 2021).

\footnotetext{
* Corresponding author
} 
Basically, these are middle-aged people who are not alien to active physical rest. In addition, the reorientation of resorts to a new market segment is associated with a reduction in financial support from municipalities and the state (Erdavletov, 2010; Egorov, 1993; Datta, 2020). It should also be said that in the domestic tourist practice the concept of "medical tourism" has received recognition only in recent years in connection with the introduction of a number of new treatment programs and foreign standards in the practice of resort business (Herman et al., 2019). Previously, the basis of medical tourism in the CIS countries, as many authors emphasize, were sanatorium and resort institutions. Therefore, it was assumed that medical tourism should be considered only within the framework of sanatorium-resort institutions. In this case, clinics, specialized medical centers, private specialists who receive tourists and vacationers at their expense in order to implement treatment and rehabilitation programs fall out of sight (Ilies et al., 2017; Jackson and Murphy, 2002; Kolesnikov, 2007).

A number of definitions do not specify a spatial criterion, that is, a criterion for a temporary change in the place of permanent residence. In particular, in the definition of medical tourism given by R.P. Sukhov (Sukhov, 2002), the distinction between medical and health tourism is carried out only on the basis of the specialization of accommodation bases, without indicating that the tourist receives medical services outside of his permanent place of residence (Nazarova et al., 2019). There is also a group of definitions in which medical and health tourism are synonymous. Medical tourism is identified with health recreation, which, depending on the means of influence on the human body, is subdivided into balneotherapy, climatotherapy and mud therapy (Mukayev et al., 2020; Nefedova et al., 1973; Vilesov et al., 2009).

There is also an approach that identifies health tourism with rehabilitation, and health tourism with recreational (Semenchenko, 2001). This approach is difficult to accept, since medical tourism cannot be limited only to rehabilitation, and the use of the term "recreational tourism" is not entirely correct methodologically, since tourism itself is a part of recreation. The object we are investigating, as a promising one for the development of medical and health tourism, is Lake Paradise, located at an altitude of 351 meters above sea level in the lower reaches of the Aksu River in the southeast of the Republic of Kazakhstan. This study has three primary objectives:

- To introduce the little-known Lake Ray to readers and government officials,

- To examine the characteristics of the lake, which have not been studied much by the scientific experts and publish the scientific results through this study,

- To promote the tourism potential of the region and draw the attention of the officials of the tourism ministry in order to enable the potential tourism investments.

\section{MATERIALS AND METHODS}

Geographic coordinates are $46^{\circ} 04^{\prime} 51^{\prime \prime}$ north latitude and $78^{\circ} 04^{\prime} 40^{\prime \prime}$ east longitude (Figure 1). The distance from the largest city of Kazakhstan Almaty to Lake Ray is $414 \mathrm{~km}$, and $154 \mathrm{~km}$ from the city of Taldykorgan. The nearby hotels, restaurants and recreation centers are located to the southwest of the unique Lake Ray in the city of Taldykorgan (Egorina et al., 2016).

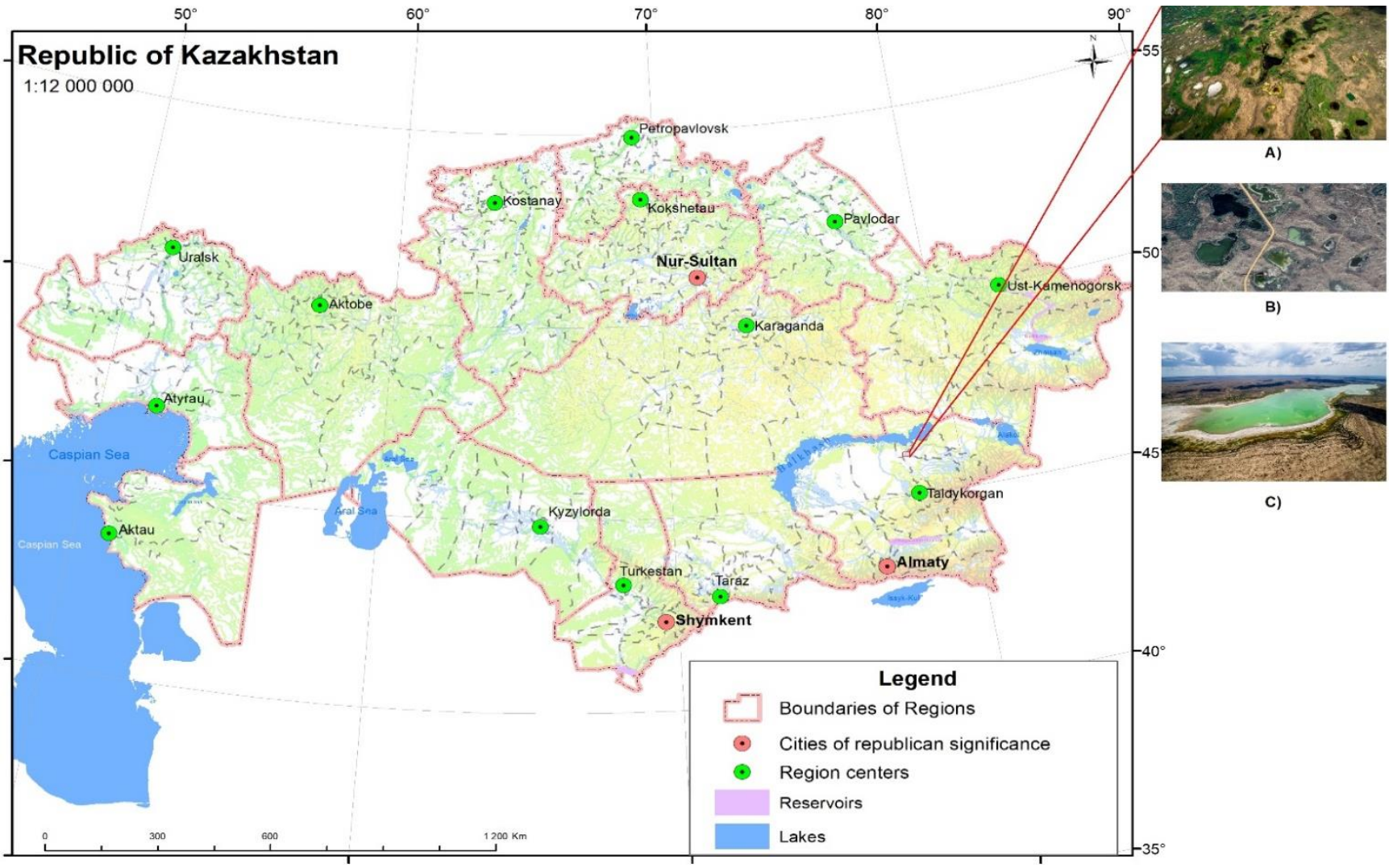

Figure 1. Geographic location of Lake Ray on the physical map of the Republic of Kazakhstan (Source: own editing with the program ArcGIS). A) Satellite image of the study area in 2020 (Lansat-8, 30 m.), B) Satellite image of Lake Ray from the SasPlatena program for 2020, C) Photo by the author of Lake Ray from an unmanned aerial vehicle (2020) 
The lake stretches from west to east. The area of the lake's water surface is about $1.2 \mathrm{~km}^{2}$, the maximum length is $400 \mathrm{~m}$, the maximum width is $150 \mathrm{~m}$, and the length of the coastline is $1150 \mathrm{~m}$. The volume of water is 156 thousand $\mathrm{m} 3$. The catchment area is $20 \mathrm{~km}^{2}$ and the average depth is 2.6 meters (Vilesov, 2009). The lake has the body of a closed inland water. Water is supplied mainly by the groundwater and melted snow water. The annual level fluctuations are about $1.1 \mathrm{~m}$. Freeze-up lasts from the first quarter of December to April. The swimming season lasts for about 2 months (from mid-June to the end of August). The peculiarity of the relief of the bottom of the lake, the basin and the nutrition generate an insignificant seasonal level of fluctuations in the water of the lake. Only with intensive melting of snow in the spring months, the area of the lake increases to $1.4 \mathrm{~km} 2$. In summer, with intense evaporation of water, the area of the water table decreases down to $1.1 \mathrm{~km}^{2}$. Between 1950-1980, Omarov and Filonets, 1970 the limnologists of the Institute of Geography of Kazakhstan studied the morphometry and content of the microelements carried out in the lake.

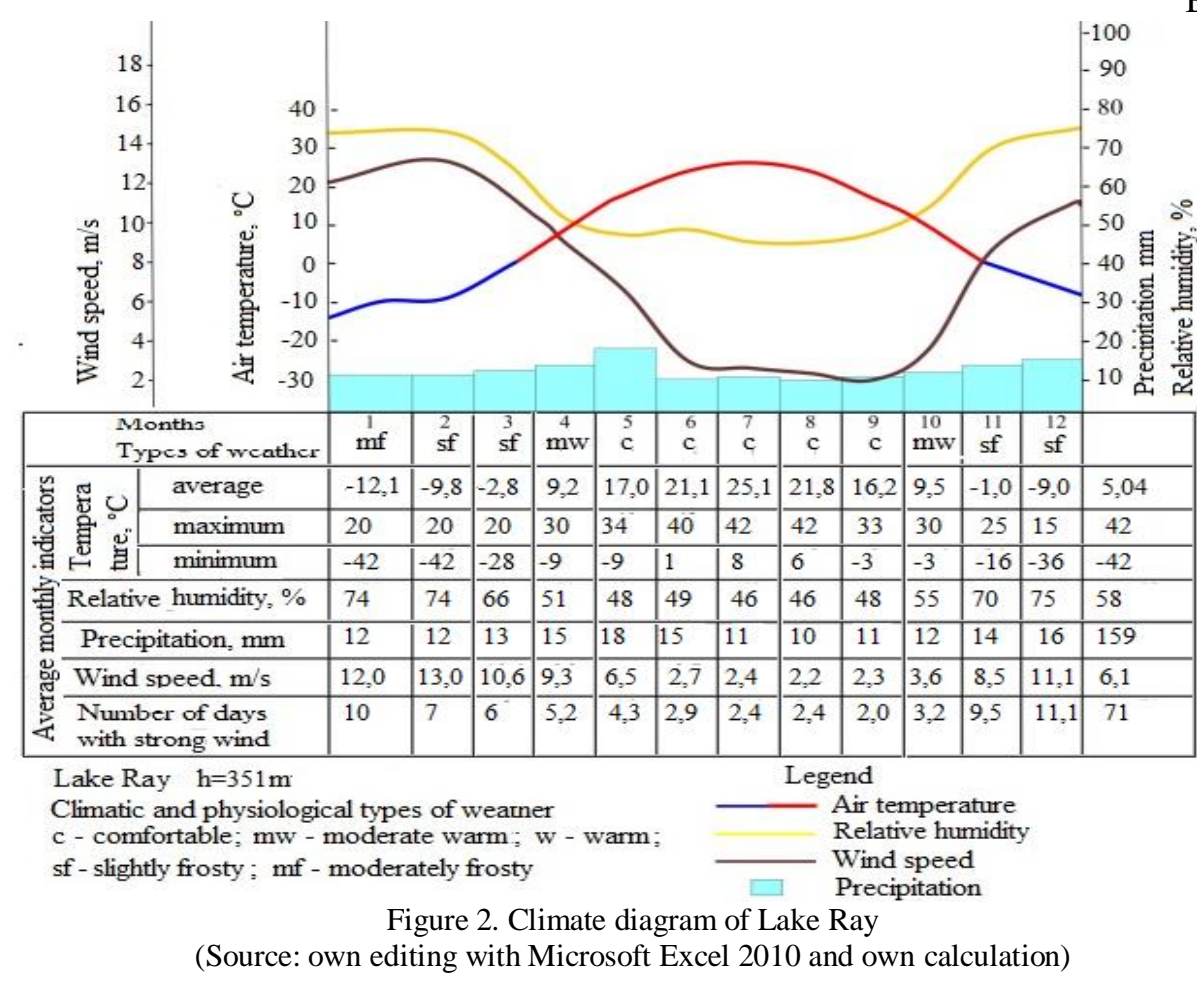

Between 1970-1980, the famous scientist V. Holenok studied the hydromineral healing resources and the balneological properties of water and the therapeutic mud of small closed lakes in the lower flow of the Aksu and the Lepsy rivers in the Balkash depression. The climate in the area of the lake is distinctively continental desert. The maximum temperature in July is around $30^{\circ} \mathrm{C}$. The average annual temperature in July, on the other hand, is $+26^{\circ} \mathrm{C}$, and around $-9^{\circ}$ $12^{\circ} \mathrm{C}$ in January. There is little precipitation, about $159 \mathrm{~mm}$ per year. Relative air humidity is 58$60 \%$ (Figure 2). The average annual wind speed is about 5.8 $6.1 \mathrm{~m} / \mathrm{s}$. Northeast winds are prevalent. The number of sunny days is between $110-130$ per year. Energy illumination is $15.9 \mathrm{MJ}$ per $\mathrm{m}^{2}$ per day. Ray is one of the warm and well-warmed salt lakes.

During the study period 2012-2015, we took water samples for physical and chemical analysis. Sampling was carried out in accordance with ST RK GOST R 51592 - 2003. In the period 2012-2015. 30 water samples were taken from Lake Rai from different depths from 10 points located at a distance of 120 meters from each other. 13 samples and curative mud were taken. The study of physical and chemical analysis of water and therapeutic mud was closely related to the problem of determining the degree of their suitability for the development of health tourism and recreation.

As a result of physical and chemical analysis, the following were determined:

1. Organoleptic characteristics of the declared sample of mud (color, smell, consistency, structure);

2. Physicochemical indicators of the declared water sample;

3. Sanitary and microbiological indicators of the declared sample of mud (Kotov et al., 2019; Margaret et al., 2018).

It was found that the presence of pollutants (detergents and heavy metals) in the peloid did not exceed the established permissible standards. According to these indicators, the state of the mud-forming reservoir was assessed as environmentally friendly (Berdenov et al., 2017). Therefore, the relevance of the study of the processes of formation, the feeding regime of water and medicinal mud of the lake, their importance for the development of health tourism was very reasonable. A "Hitachi" atomic absorption spectrometer, model 180-50 (Japan), a PFP7 flame photometer (Great Britain) and optical emission spectrometer with inductively coupled plasma Optima 2000 DV (USA), electric autoclave in accordance with GOST 9586-61, biological microscope in accordance with GOST 8284-78 LeicaDMLS brand with digital video camera LeicaDC $300 \mathrm{~F}$ were used to obtain sample analyzes.

\section{RESULTS DISCUSSIONS}

As a result of water evaporation in summer, the level of the lake decreases by 0.5-0.8 m. However, it does not dry up due to the supply of groundwater. This also explains the similarity of the chemical composition of sea and lake waters, which belong to the same type - sodium chloride-sulfate. Unlike the sea, the water of Lake Ray is more mineralized. Total mineralization of water with increased evaporation of water in the summer months reaches $140 \mathrm{~g} / \mathrm{l}$. Salt marshes are formed on the shore of the lake as a result of water evaporation in summer, and are saturated with various chemical elements that are beneficial to human health. The etymology of the lake is associated with the name of a man who lived in this area in the middle of the XX century, who treated wounded soldiers during the Great Patriotic War between 1941-1945. The 
physicochemical composition of the water and therapeutic mud of the Lake Ray are rich in in various microelements useful for the human body. Further study of the physical and chemical characteristics of water and the healing properties of mud will provide scientific justification for the planning and design of seasonal health resorts specializing in heliotherapy, thalassotherapy, climatotherapy, and mud therapy. The mineral substrate that forms the mud, the quality and amount of organic matter involved in mud formation, the liquid medium in which mud-forming processes take place and microbes that cause these processes are the main factors of peloid formation in Lake Ray. Mineralization of water in the lake has a certain effect on the intensity of mud-forming processes. Their speed slows down in waters with very high salinity. The thermal regime of the reservoir, the feeding conditions of the lake, and the adsorption of substances is an important factor. The ability of bottom sandy and clayey sediments to adsorb bacteria enhances the intensity of mud formation processes (Gomes et al., 2013).

Expeditionary analysis carried out in order to study the suitability of water and therapeutic mud showed that the drainlessness and shallowness of the waters, active evaporation of water in the summer months had an impact over the chemical and mineral composition of the water of Lake Ray (Table 1). The results of laboratory analysis of the samples taken

Table 1. Results of the spectral analysis of Lake Ray's water

\begin{tabular}{|c|c|c|c|}
\hline $\begin{array}{c}\text { Chemical } \\
\text { elements in the } \\
\text { composition } \\
\text { water }\end{array}$ & $\begin{array}{c}\text { Dissolved } \\
\text { chemical } \\
\text { elements, } \\
\mathrm{g} / \mathrm{l}\end{array}$ & $\begin{array}{c}\text { Chemical } \\
\text { elements in the } \\
\text { composition of } \\
\text { water }\end{array}$ & $\begin{array}{c}\text { Dissolved } \\
\text { chemical } \\
\text { elements, } \\
\mathrm{g} / \mathrm{l}\end{array}$ \\
\hline Ammonia & 0,00036 & Phosphates & 0,0001 \\
\hline Chloride & 45,631 & Iron & 0,0001 \\
\hline Calcium & 0,016 & Lead & 0,0013 \\
\hline Fluorides & 0,00338 & Sodium & 54,63 \\
\hline Magnesium & 0,559 & Potassium & 0,102 \\
\hline Nitrites & 0,0021 & Iodites & 0,00055 \\
\hline Carbonates & 2,64 & Bromites & 0,03096 \\
\hline Hydrocarbonates & 3,5757 & Boron & 0,009 \\
\hline Sulfates & 32,537 & $\begin{array}{c}\text { Total } \\
\text { mineralization }\end{array}$ & 139,72 \\
\hline
\end{tabular}

Note: The data in Table 1 was compiled on the basis of analysis of laboratory data from a laboratory study of water from Lake Ray of the National Scientific Laboratory of the Joint-Stock Company "Center for Earth Sciences, Metallurgy and Enrichment" of the Science Committee of the Ministry of Education and Science of the Republic of Kazakhstan showed that the water was clear, the total hardness $115 \mathrm{~mol}$, the $\mathrm{pH}$ of the western part 8.95 , and the eastern part 9 . There were more sulfates $(32.557$ $\mathrm{g} / \mathrm{l})$, chlorides $(5.63 \mathrm{~g} / \mathrm{l})$, hydrocarbonates $(2.64 \mathrm{~g} / \mathrm{l})$, bromides $(0.031 \mathrm{~g} / \mathrm{l})$, magnesium $(0.559 \mathrm{~g} / \mathrm{l})$ than calcium $0.016 \mathrm{~g} / \mathrm{l})$ in the water. The total mineralization is $139.72 \mathrm{~g} / \mathrm{l}$. The concentration of magnesium, chloride, hydrocarbonate and calcium in the composition of water complied with the limiting standards (Table 2). The mineralization of the lake water was significantly influenced by the groundwater supply and high evaporation during the summer months. Laboratory analysis of the water samples taken from this lake showed that the composition of the water belonged to the sulfatechloride-sodium waters and met the sanitary and epidemiological requirements in line with the resolutions of the Government of the Republic of Kazakhstan dated January 18, 2012 No. 104**. Therefore, the waters of this lake can be used for the development of health tourism and recreation. 13 chemical elements of the periodic table were identified in the composition of the water sample from Lake Ray. Among them, sodium (54630.1 mg/l), magnesium (559.4 mg/l), potassium (102.0 mg/l), chlorides (45631.2 mg/l), hydrocarbonates $(3575.7 \mathrm{mg} / \mathrm{l})$, carbonates $(2640.0 \mathrm{mg} / \mathrm{l})$, sulfates $(32537.0 \mathrm{mg} / \mathrm{l})$ were present. A comparative analysis of the data of laboratory studies of water samples in different seasons showed the difference in the cations and anions found in the western and eastern parts of Lake Ray (Table 2 and Table 3). The data analysis of the chemical composition of the waters in the eastern part of the lake in comparison with the western part of the Na was more by $7571.6 \mathrm{mg} / \mathrm{l}$ (13.85\%); magnesium $4.9 \mathrm{mg} / \mathrm{l}(0.87 \%)$; chloride $423.5 \mathrm{mg} / \mathrm{l}(0.92 \%)$; more sulfate by $218.2 \mathrm{mg} / 1(0.67 \%)$, and less potassium by $29.5 \mathrm{mg} / \mathrm{l}(22.43 \%)$, carbonates $12 \mathrm{mg} / \mathrm{l}(0.45 \%)$; and bromides $8.53 \mathrm{mg} / \mathrm{l}(8.67 \%$ ) (Table 2 and Table 3 ).

Table 2. Results of the spectral analysis of water in the eastern part of Lake Ray

\begin{tabular}{|c|c|c|c|c|c|c|c|}
\hline \multicolumn{5}{|c|}{ Found cations } & \multicolumn{5}{c|}{ Found anions } \\
\hline components & $\mathrm{mg} / \mathrm{dm}^{3}$ & $\mathrm{meq} \mathrm{dm}^{3}$ & $\mathrm{meq} \mathrm{dm}^{3} / \%$ & components & $\mathrm{mg} / \mathrm{dm}^{3}$ & $\mathrm{meq} \mathrm{dm}^{3}$ & $\mathrm{meq} \mathrm{dm}^{3} / \%$ \\
\hline Sodium & 54630,1 & 2375,22 & 98,0 & Carbonates & 2640,0 & 88,0 & 3,6 \\
\hline Potassium & 102,0 & 2,62 & 0,1 & Hydrocarbonates & 3575,7 & 58,6 & 2,4 \\
\hline Calcium & 16,0 & 0,80 & 0,0 & Chlorides & 45631,2 & 1600,0 & 66,0 \\
\hline Magnesium & 559,4 & 46,00 & 1,9 & Sulfates & 32537,0 & 677,43 & 27,9 \\
\hline Ammonium & 0,2 & 0,01 & 0,00 & Fluorides & 4,35 & 0,23 & 0,01 \\
\hline Iron (+3) & 0,1 & 0,01 & 0,0 & Iodites & 0,55 & 0,004 & 0,000 \\
\hline & & & & Bromites & 30,96 & 0,39 & 0,02 \\
\hline & & & & Boron & 9,00 & & \\
\hline
\end{tabular}

Table 3. Results of the spectral analysis of water in the western part of Lake Ray

\begin{tabular}{|c|c|c|c|c|c|c|c|}
\hline \multicolumn{4}{|c|}{ Found cations } & \multicolumn{4}{c|}{ Found anions } \\
\hline components & $\mathrm{mg} / \mathrm{dm}^{3}$ & meq $\mathrm{dm}^{3}$ & meq $\mathrm{dm}^{3} / \%$ & components & $\mathrm{mg} / \mathrm{dm}^{3}$ & $\mathrm{meq}^{3}$ & $\mathrm{meq}^{3} \mathrm{dm}^{3} / \%$ \\
\hline Sodium & 47058,5 & 2046,02 & 97,6 & Carbonates & 2652,0 & 88,4 & 4,2 \\
\hline Potassium & 131,5 & 3,37 & 0,2 & Hydrocarbonates & 3563,5 & 58,4 & 2,8 \\
\hline Calcium & 8,0 & 0,40 & 0,0 & Chlorides & 45207,7 & 1275,0 & 60,8 \\
\hline Magnesium & 554,5 & 45,60 & 2,2 & Sulfates & 32318,8 & 672,89 & 32,1 \\
\hline Ammonium & 0,2 & 0,01 & 0,00 & Fluorides & 4,06 & 0,21 & 0,01 \\
\hline Iron $(+2)$ & - & - & - & Iodites & 1,47 & 0,012 & 0,001 \\
\hline Iron $(+3)$ & 0,1 & 0,01 & 0,0 & Bromites & 39,53 & 0,49 & 0,02 \\
\hline
\end{tabular}


Based on this, we can conclude that the increased concentration of salts of sodium, potassium, other metals and sulfate increases the healing properties of the lake. This allows the lake to be used for medical and recreational purposes.

Spectral analysis of the water in the eastern part of the lake showed that the $\mathrm{pH}$ was 8.95; total mineralization 139.72 $\mathrm{g} / \mathrm{l}$; dry residue $1486.96 \mathrm{mg} / \mathrm{eq} / \mathrm{dm}^{3}$; and total water hardness $46.00 \mathrm{~mol}$; parchment oxidation -

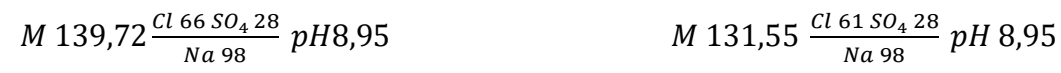

Spectral analysis of the water in the western part of the lake showed a $\mathrm{pH}$ of 8.95 ; total mineralization of water was $131.55 \mathrm{~g} / \mathrm{l}$; dry residue $1233.24 \mathrm{mg} / \mathrm{eq} / \mathrm{dm} 3$; and total hardness $46.00 \mathrm{~mol}$; parchment oxidation -

As a result of the performed spectral analysis of the curative mud samples, 9 chemical elements were identified. Among them, the composition of peloids was dominant by $\mathrm{Cu} 4.6 \mathrm{mg} / \mathrm{kg}$; Ni $11.3 \mathrm{mg} / \mathrm{kg} ; \mathrm{Pb} 3.036 \mathrm{mg} / \mathrm{kg} ; \mathrm{Cd} 0.04 \mathrm{mg} / \mathrm{kg}$; Mn $15.98 \mathrm{mg} / \mathrm{kg}$; As $8.12 \mathrm{mg} / \mathrm{kg}$; Zn $9.7 \mathrm{mg} / \mathrm{kg}$; and Cr $0.02 \mathrm{mg} / \mathrm{kg}$.

According to doctors of balneologists, iodine, bromine and other microelements in the composition of the water and therapeutic mud of the lake are of great importance for cleansing the digestive system, regulating the work of the cardiovascular and musculoskeletal systems, and treating the thyroid gland, skin and gynecological diseases (Ushakov et al., 2019). A laboratory analysis of the chemical composition of the water and therapeutic mud of this lake showed that many microelements would have a positive effect on the human body, which would eventually make it possible to develop health tourism and recreation in Lake Ray. Due to a wide range of chemical elements, water enters into the body through the skin, making its way into the bloodstream and has a very positive healing effect on the body. For instance, acting directly on the skin, it causes a number of neuro-reflex reactions and has a rejuvenating effect as well.

A good example and standard is the city of Sol-Iletsk in the Orenburg region of the Russian Federation, being an industrial center in the 19th century, at the beginning of the 20th century it was renamed into a resort city, in the early 2000s the city became a well-known center of health tourism in Russia, and is now known in all CIS countries. The city is known for its unique lakes with various concentrations of salt and healing mud. Today, the resort has seven unique lakes in terms of the chemical composition of water. They are small - more like natural baths or springs for hydrotherapy. But their healing power is great. Today the city has over 850 guest houses and hotels. Also, work continues on the development of the infrastructure of the city of Sol-Iletsk and attracting investments (Sokolova, 2004; Demir, 2014).

\section{CONCLUSION}

Lake Ray is a small lake that is not connected to other lakes or seas and has a closed basin feature. However, the fact that lake water and lake mud have healing power indicates that health tourism can develop in the region. The composition of the healing mud of Lake Ray is dominated by ions of magnesium, calcium, sodium, copper, chromium, manganese. The analysis of the research results showed that the physicochemical composition of water and brine met the regulatory sanitary and epidemiological requirements and could be used in stationary medical institutions and physiotherapy. The analysis carried out, it is possible to conclude that Lake Ray in the Republic of Kazakhstan has a unique variety of hydromineral recreational resources. However, their use for recreational and health-improving purposes, unfortunately, is not up to the mark. Therefore, it is necessary to develop a sanatorium-resort and healthimproving infrastructure, as well as streamlining and improving the efficiency of using the recreational resources of this lake. Inadequate transportation connections, insufficient number of accommodation facilities, incompetent publicity and undeveloped tourist infrastructure negatively impact the tourism activities in the region.

Thanks to the tourism investment programs to be organized by the government of Kazakhstan and the Ministry of Tourism, Lake Ray and its surroundings can be transformed into a new tourism center. As it stands today, it is clearly observed that no recreation and tourism investments have been made on the shores of the lake. Geographic factors for the development of health tourism on Lake Paradise are associated with the fact that there are healing springs, healing mud, unique minerals - tools for treating people, and also important is the location in the south, with a favorable climate. It is necessary to pay attention to the organization of health tourism, and create the conditions for a modern resort.

Factors available:

- availability of medicinal resources that ensure the development of the resort;

- availability of infrastructure for health tourism - swimming pools, beaches.

Factors requiring development:

- availability of medical and preventive establishments - hotels, clinics, sanatoriums, where medical care for patients is provided;

- availability of entertainment infrastructure - cinemas, libraries, sports grounds, since the main goals of health tourism are not only therapy, but also good rest;

- availability of catering establishments, shops, hairdressing salons, where visitors can fulfill their everyday needs.

\section{REFERENCES}

Akhmedenov, K.M. (2020). Tourist and recreational potential of the salt lakes of Western Kazakhstan. GeoJournal of Tourism and Geosites, 30(2spl), 782-787. https://doi.org/10.30892/gtg.302spl01-505

Akhmedenov, K., Petrishchev, V., Noreika, S., \& Ramazanov, S. (2017). Perspektivy sozdaniya osobo ohranyayemoi pripodnoi territorii "Gora Maloye Bogdo" [Prospects for the creation of a specially protected natural area "Mount Maloe Bogdo"]. Voprosy geografiii geoekologii (Geography and Geoecology Issues), 3, 3-18 (in Russian). 
Beketova, A., Berdenov, Z., Mendybayev, E., Safarov, R., Shomanova, Z., \& Herman, G.V. (2019). Geochemical monitoring of industrial center for development of recreational areas (on the example of Khromtau-Don industrial hub, Kazakhstan). GeoJournal of Tourism and Geosites, 27(4), 1449-1463. https://doi.org/10.30892/gtg.27428-447

Berdenov, Z., Mendibaev, E., Salihov, T., Akhmedenov, K., \& Ataeva, G. (2017). Geoecological analysis of industrial cities: On the example of Aktobe agglomeration. Chemistry. 26(6), 890-902.

Carretero, M.I., Pozo, M., Legido, J.L., Fernández-González, M.V., Delgao, R., Gómez, I., Armijo, F., \& Maraver, F. (2014). Assessment of three Spanish clays for their use in pelotherapy. Applied clay science, 99, 131- 143. http://dx.doi.org/10.1016/j.clay.2014.06.022

Constable, P., (2007). The Challenge of France's 'Great Lake'. Project, In: Németh, Á. And Dávid, L. (Eds) Handbook of Lakes and Reservoirs. A Sustainable Vision is Tourism, 26-33. (Gyöngyös: Department of Tourism and Regional Development, Károly Róbert College)

Datta, B. (2020). Factors affecting the satisfaction level of medical tourists: a case study of Delhi National Capital region. GeoJournal of Tourism and Geosites, 29(2), 628-635. https://doi.org/10.30892/gtg.29219-494

Demir, K. (2014). Recreational potential of health tourism in Russia / K. Demir. - M.: LAP Lambert Academic Publishing, 272, (in Russian)

Dunets, A., Muhamedieva, A., Sycheva, I., Perepechkina, E., Vakhrushev, I., \& Kulchytskiy, A. (2019). Spatial tourism planning: Using the model of functional and planning complexes. Journal of Environmental Management and Tourism, 10(4), 711-719. https://doi.org/10.14505/jemt.v10.4(36).01

Dracheva, E.L. (2010). Special types of tourism. Medical tourism: textbook. allowance / E.L. Dracheva. - M. KNORUS, P. 144. (in Russian)

Egorina, A.V., Kaliakperova, N.Z., \& Kanatkyzy, N. (2016). Recreational opportunities of East Kazakhstan for tourism development. International Journal of Applied and Fundamental Research, 3, 298-302.

Egorina, A., Saparov, K.T., \& Zhensikbayeva, N.Z. (2016). The Structure of the Geo-Cultural Space of Southern Altai as a Factor of Tourist-Recreational Development, in: Vestnik, KNU, Scientific Journal. Almaty, 214-219.

Egorina, A.V. (2015). The Climate of Southwest Altai. Textbook, Semey, 315.

Egorov, A.N. (1993). Mongolian salt lakes: some features of their geography, thermal patterns, chemistry and biology. Hydrobiologia, 267, 13-21. https://doi.org/10.1007/bf00018788

Erdavletov, S.R. (2010). Tourism history. Development and scientific study. Almaty: Atamura, 336

Filonets, P.P., \& Omarov, T.R. (1970). The content of trace elements in surface waters-Taldy-Kurgan and Alma-Ata regions. AlmaAta, 175, (in Russian).

Gomes, C., Carretero, M.I., Pozo, M., Maraver, F., Cantista, P., Armijo, F., \& Delgado, R. (2013). Peloids and pelotherapy: Historical evolution, classification and glossary. Applied Clay Science, 75, 28-38.

Herman, G.V., Wendt, A.J., Dumbravă, R., \& Gozner, M. (2019). The role and importance of promotion centers in creating the image of tourist destination: Romania. Geographia Polonica, 92(4), 443-454. https://doi.org/10.7163/GPol.0158

Ilies, A., Hurley, P.D., Ilies, D.C., \& Baias, S. (2017). Tourist animation -a chance adding value to traditional heritage: case studys in the Land of Maramures (Romania). Revista de Etnografie si Folclor, 1-2(1-2), 131-151.

Jackson, J., \& Murphy, P. (2002). Tourism Destinations as Clusters: Analytical experiences from the New Word. Tourism and Hospitality Research, 4(1), 36-52.

Khomitch, S., Ramanchuk, A., Daniltchenko, A., \& Rzętała, M. (2019). Key factors for tourist and recreational use of quarry ponds of Belarus and Poland. GeoJournal of Tourism and Geosites, 27(4), 1114-1133. https://doi.org/10.30892/gtg.27401-420

Kolesnikov, D.A. (2007). A review of existing methods for assessing recreational areas. GeoSiberia 2007-International Exhibition and Scientific Congress, 6, 206-209.

Kotov, S., Kotova, I., \& Kayukova, E. (2019). Geological controls and the impact of human society on the composition of peloids of present-day salt lakes (coastal zones of the Black, Azov, and Dead Seas). Journal of Coastal Conservation, 23(4), 843-855.

Margaret, S.M., Nadia, M.V., Patricia, G.H., Clara, M.R., Josiel, B.C., Rebeca, H., \& Cristina, D.L. (2018). Physicochemical characterization, elemental speciation and hydrogeochemical modeling of Santa Lucía peloid used for therapeutic uses. Revista Internacional de Contaminacion Ambiental, 34, 105-110.

Mukayev, T.Z., Ozgeldinova, O.Z., Janaleyeva, M.K., \& Zhanguzhina, A.A. (2020). Assessment of the tourist recreation capacity of lake Alakol basin. GeoJournal of Tourism and Geosites, 30(2spl), 875-879. https://doi.org/10.30892/gtg.302spl13-517

Nazarova, T.V., Fomin, I.A., Dmitriev, P.S., Wendt, J.A., \& Janaleyeva, K.M. (2019). Landscape and limnological research of lake systems of the plain areas of the northeastern borderlands of the Republic of Kazakhstan and assessment of their recreational capacity. GeoJournal of Tourism and Geosites, 25(2), 485-495

Nefedova, V., Smirnova, Y., \& Shvidchenko, L. (1973). Methods of recreational assessment. Bulletin of Moscow State University. Series Geography, 5, 25-29.

Semenchenko, S.I., (2001). Balneological resorts of the Russian Federation. Cherkasy, 89.

Sokolova, M.V., (2004). History of tourism / M.V. Sokolov. - M .: Academy, 123 p. (in Russian)

Sukhov, R.I., (2002). Features of development and the current state of tourism in the Rostov region. Abstract of the dissertation of geographical science. Rostov-on / Don, 23, (in Russian).

Suleimenov I.,Bakirov A.,Niyazova G.,Shaltykova D. (2021). University as an analogue of the neural network. E3S Web Conf., Vol.258 (07056). https://doi.org/10.1051/e3sconf/202125807056

Ushakov, D.S., Yushkevych, O.O., Ovander, N.L., Tkachuk, H.Y., \& Vyhovskyi, V.H. (2019). The strategy of thai medical services promotion at foreign markets and development of medical tourism. GeoJournal of Tourism and Geosites, 27(4), 1429-1438. https://doi.org/10.30892/gtg.27426-445

Vilesov, E., Naumenko, A., Veselova, L., \& Aubekerov, B. (2009). Phizicheskaya geographiay Kazahstana [Physical geography of Kazakhstan]. Edited by Vilesov, E., Naumenko, A., Veselova, L., Aubekerov B. Almaty: Kazakh University, Kazakhstan, (in Russian).

*** National Atlas of the Republic of Kazakhstan (2010). Volume 1: Natural conditions and resources / Editor-in-chief Medeu A.R. Almaty: Parasat, 150.

***Resolution of the Government of the Republic of Kazakhstan dated January 18, 2012 No. 104. On approval of the Sanitary Rules Sanitary and Epidemiological Requirements for Water Sources, Water Intake Points for Household and Drinking Purposes, Household and Drinking Water Supply and Places of Cultural and Household Water Use and Safety of Water Bodies. https://adilet.zan.kz/rus/docs/P1200000104/history. 